\section{The Effect of Compensation Studies on Disadvantaged Children's Bully Behaviours}

\author{
Gönül Onur Sezer a
}

$\begin{array}{ll}\text { Received: } & 9 \text { October } 2017 \\ \text { Revised: } & 24 \text { November } 2017 \\ \text { Accepted: } & 28 \text { November } 2017 \\ \text { ISSN: } 1307-9298 \\ \text { Copyright @ IEJEE } \\ \text { www.iejee.com }\end{array}$

DOI: $10.26822 /$ iejee.2017236117

\begin{abstract}
Children who are economically, educationally, linguistically or socially disadvantaged called "disadvantaged children". Those children are at risk and they must be supported because of their negative life conditions. Compensation studies must be implemented to those children. The "Bir Umut Ol Benim Için" (Be My Hope) project is such a compensation study which is held by Uludag University Faculty of Education and Bursa Police Department Children Branch Office. The aim of this study is to determine the impact of this project on disadvantaged children's bullying behaviours. In line with this objective Colorado School Climate Survey, which was developed by Garrity et al., (2000) was used. The questionnaire was designed to measure several aspects of bullying. The analyses of the study showed that the project "Bir Umut Ol Benim Için" has not caused a positive effect on the bully behaviours. While it was hoped that this project would cause a decrease in bully behaviours of disadvantaged children because it is a compensation study, it is seen that such as studies/projects must be sup ported with bully proofing and with conflict resolution programs.
\end{abstract}

Keywords: Disadvantaged children, bully behaviour, compensation study, risk factor.

\section{Introduction}

Some children are economically, educationally, linguistically or socially disadvantaged. They lack of the basic necessities of life, they have been denied the basic and universal rights of children, the opportunity to grow normally at their own natural rate. The term of "disadvantaged children" is used to specify those children who are subjected to detrimental environmental stresses of any kind and handicapped or disabled because of certain conditions of exogenous risks and lastly, who are at risk of future psycho-educational problems (Dash, 2007; Moore, 2006). Schatz, Smith, Borkowski, Whitman and Keogh (2008) stated that, ill-treated children are more capable of showing withdrawn behaviours, social problems and bully behaviours, get lower grades and fail the class. Supportive studies such as compensative studies must be implemented for those children. Compensation studies which require a sophisticated and comprehensive study consist of activities aiming to overcome the problems created by existing risk factor (Kırcaali iftar, 2007).

Compensation studies help disadvantaged children to overcome this disharmony social organization (Smith et al., 2004). These compensation studies aim to help the children readjust and require a suitable education and training program that is prepared with pedagogic and scientific approach by determining their intelligence, characteristics, talents, and closely observing his development stage. Thereby, it is intended to help the child develop his lacking behaviours and become an individual that can obey social rules (Sarpdağ, 2005). The studies about bullying started in later 1970s, especially in Norway, Sweden and Finland. Particularly, "Bullying in Schools", the book published in 1978 by the Norwegian researcher Dan Olweus, is taken as a milestone in bullying. Recently these studies have increased in England, Australia and the USA. While there is not a universal definition about bullying, researchers generally defines bullying as repetitive bully behaviours, asymmetric power relations or systematic abuse of power (Olweus, 1999). Some researchers identified the bullying as intentional bully behaviours against others; some others state that, in order to consider these kinds of behaviours as bullying, they have to be repeated regularly (Griffin \& Gross, 2004).

The commonly used definition belongs to Olweus (1987): "If a person is confronted with intentional, repetitive and continuing negative behaviours at least for a while by another person or persons, it can be said that this person is sustained from bullying". Negative behaviours are explained as behaviours that hurt and bother someone intentionally or the behaviours that try to do this. This definition enables us to differentiate the random bully behaviour from bullying (Griffin \& Gross, 2004). Dominant person(s) harm(s) the less dominant people intentionally and repetitively. This bully behaviour may be direct or indirect, both physically (for example; kick, hit) or orally (for example; nicknaming). Direct bullying occurs by definite bullying such as hitting, pushing, japing, menacing and damaging the properties that the other person had. On the other hand, indirect bullying which is carried out via behaviours that do not necessitate the person who bullies and the bully victim to meet directly such as

a Correspondence details: Gönül Onur Sezer, Uludag University, Faculty of Education, Department of Elementary Education, Room Number: 206, Gorukle Campuss, 16059, Bursa, Turkey. E-Mail: gonulonur@uludag.edu.tr 
excluding from the social group, spreading rumours and humiliating. By this way the status and sense of the victim is changed by the others. This kind of bullying is also detrimental at least as much as direct bullying; however it has entered the field of psychosocial research recently (Connor, 1998).

Bullying causes serious problems for victims and bullies. Broken down of the school climate and the training of children in a safe environment because of bullying in short term, may cause toddling off from the school, degeneration of psycho-social conformity, criminal behaviours and apprehension, loneliness and depression for the victims in the long term (Scarpaci, 2006). The most important long term effect of bullying is the misuse of intensity and power. A high correlation is appointed between the bully behaviours in primary school and crime rate that arise in the upcoming years (Olweus, 1993). At the same time, the tendency of victims about their selfconfidence to be lower at adulthood (Byrne, 1994). Ersanlı (2007) states that punishment has been considered to be the only method for authority and deterrence up until today but studies such as compensation studies, towards reserializing and deterrence have gained importance in recent years. The aim of the project "Be My Hope", which was applied in Bursa during spring semester of the year of 2011-2014 and carried out by volunteer teacher candidates and children under the risk in cooperation with the Children Branch Office of Bursa Police Department and the Faculty of Education of Uludag University, is to provide that primary education students in the risk group who cannot benefit from equal opportunities like students of the same age because of unfavourable conditions of the environment where they live, conduct academic and social activities with teacher candidates who receive education in the Faculty of education. In addition teacher candidates become role models and that these children are reintegrated into the society as individuals who have respect for themselves and environment, who are happy, active and productive. Another purpose of the project is to perform academic and social activities to the children who are under risk and cannot have the equal opportunities with their peers due to the unfavourable environment they have lived with teacher candidates. In this way these children would be reintegrated into the society by being self and environment respecting, happy, effective and productive individuals. At the same time during the project the teacher candidates would be the role model for those children. Within the context of the project, the academic studies, social and sports activities are organized for the academic and social development of the children under risk.

\section{The Aim of the Study}

"Bir Umut Ol Benim Için" project is a study that encourages the academic and social development of children under risk, to reintegrate into the society as healthy, happy and productive individuals. From this point forth, the aim of this study is to examine the effect of the study of compensating the risk factors on the bullying behaviours of children, who were qualified as disadvantaged, within the scope of the project. Therefore this study is important for being a research to the body of literature.

\section{Methodology}

For the purpose of the project, children chosen by Bursa Provincial Security Directorate's Child Branch benefit from this process by participating individually or as a group in academic and social activities with volunteer teacher candidates during planned days and hours. Within the scope of this Project study times, social activities and sport activities are held for their academic developments by teacher candidates and disadvantaged children in recreational and sports facilities provided by Metropolitan Municipality of Bursa. Teacher candidates organize study times for academic development of disadvantaged children groups in environments provided by City Council. In these studies, Bursa Provincial Security Directorate's Child Branch locates disadvantaged children, obtains the consent of families, transports children to related study areas and provides security during the process of studies. The explanations about the model of the study, study group, data collection tools and statistical techniques that were used in the analysis of the collected data are included in this section.

\section{Research Model}

This research is carried out in conformity within the scope of a project and the results of the pre-test and post-test were examined, which aims to test the significant difference between the related two surveys. It is examined in the study that whether there were significant differences between the pre-test and post-test scores of Colorado School Climate Survey (Garrity, Jens, Porter, Sager \& Short-Camilli, 2000) including the statements for the determination of bully behaviours of the children who had attended the study.

\section{Participants}

The participants of the study consisted of 33 children, who were evaluated as disadvantaged by Bursa Police Department Children Branch Office and who were included in "Bir Umut Ol Benim İçin" project. The information about the children, who attended the study, is shown in Table 1.

Table 1. Descriptive Statistics about the Children Who Attended the Project

\begin{tabular}{|c|c|c|c|}
\hline & & $N$ & $\%$ \\
\hline \multirow{2}{*}{ Gender } & Girl & 5 & 15.2 \\
\hline & Boy & 28 & 84.8 \\
\hline \multicolumn{2}{|c|}{ Total } & 33 & 100 \\
\hline \multirow{5}{*}{ Class } & 5. Grade & 1 & 3 \\
\hline & 6. Grade & 25 & 75.8 \\
\hline & 7. Grade & 3 & 9.1 \\
\hline & 8. Grade & 4 & 12.1 \\
\hline & & 33 & 100 \\
\hline \multirow{5}{*}{ Age } & 11 & 1 & 3 \\
\hline & 12 & 13 & 39.4 \\
\hline & 13 & 14 & 42.4 \\
\hline & 14 & 5 & 15.2 \\
\hline & Total & 33 & 100 \\
\hline
\end{tabular}


When Table 1 is examined, it is seen that 33 children 5 of which (15.2\%) are girls and 28 of which $(84.8 \%)$ are boys. $42.2 \%$ of the children are $13 ; 39.4 \%$ are $12 ; 15.2 \%$ are 14 and $3 \%$ are 11 years old. $75.8 \%$ of the children are in 6 . grade, $12.1 \%$ to 8 . grade, $9.1 \%$ to 7 . grade and $3 \%$ to 5 . grade.

\section{Data Gathering Tools}

In this study the Colorado School Climate Survey, which was developed by Garrity et al, as a part of a bully proofing program for schools was used. (2000). The Turkish form of this questionnaire with some small modifications has been done by three educational psychologists Kartal and Bilgin (2007; 2008; 2009). The questionnaire form consists of the statements about who had done the bullying, the places where they suffered from bullying, to whom they had explained the bullying. The questionnaire was 4-point Likert type. In this study, in the beginning of the project the Cronbach Alpha coefficient was determined as .62 and in the end of the project it was found as .75 .

\section{Data Analysis}

The pre-test and post test scores obtained from the questionnaire was given in findings section by being analysed with chi-square $\left(X^{2}\right)$ test and the results were achieved after they have been interpreted in later sections. In the analysis of the data, the difference between student pre-test and post-test reports in terms of the proportions of bullying types and bully Kay-Square test was carried out to determine if it was significant. The significance value was set at .05 .

\section{Results}

When Table 2 is examined, a significant difference is identified between the pre-test and post-test percentages of the answers to the item "Other children hit or kicked $m e^{\prime \prime}\left[X^{2}(g)=20.621, p<.05\right]$. An increase is observed in the post test percentages of the children who said "Never" and a decrease is observed in the percentages of the children who said "once a week", "2-4 times a week" and "more than 5 times a week".

Table 2. The Chi-square Test Results about the Comparison of the Pre-Test and Post-Test for the Bully Behaviours the Children Suffer From and Their Frequency

\begin{tabular}{|c|c|c|c|c|}
\hline During the last month & & Pre-test (\%) & Post-test (\%) & $p$ \\
\hline \multirow{4}{*}{$\begin{array}{l}\text { Other children hit or } \\
\text { kicked me }\end{array}$} & Never & 51.5 & 66.7 & \multirow{4}{*}{$.014^{*}$} \\
\hline & Once a week & 33.3 & 24.2 & \\
\hline & 2-4 times a week & 6.1 & 3.0 & \\
\hline & More than 5 times a week & 9.1 & 6.1 & \\
\hline \multirow{4}{*}{$\begin{array}{l}\text { Other children spoke ill of } \\
\text { me, ridiculed me or } \\
\text { nicknamed me }\end{array}$} & Never & 62.5 & 53.1 & \multirow{4}{*}{$.010^{*}$} \\
\hline & Once a week & 21.9 & 28.1 & \\
\hline & 2-4 times a week & 6.3 & 6.3 & \\
\hline & More than 5 times a week & 9.4 & 12.5 & \\
\hline \multirow{4}{*}{$\begin{array}{l}\text { Other children did not let } \\
\text { me join them }\end{array}$} & Never & 78.8 & 81.8 & \multirow{4}{*}{$.000 *$} \\
\hline & Once a week & 15.2 & 9.1 & \\
\hline & 2-4 times a week & 3.0 & 3.0 & \\
\hline & More than 5 times a week & 3.0 & 6.1 & \\
\hline \multirow{4}{*}{$\begin{array}{l}\text { Other children took the } \\
\text { things that belonged to } \\
\text { me. }\end{array}$} & Never & 56.3 & 78.1 & \multirow{4}{*}{$.001 *$} \\
\hline & Once a week & 28.1 & 12.5 & \\
\hline & 2-4 times a week & 12.5 & 3.1 & \\
\hline & More than 5 times a week & 3.1 & 6.3 & \\
\hline \multirow{4}{*}{$\begin{array}{l}\text { Other children } \\
\text { threatened me to hurt } \\
\text { me and to take my } \\
\text { objects. }\end{array}$} & Never & 83.9 & 83.9 & \multirow{4}{*}{.858} \\
\hline & Once a week & 9.7 & 3.2 & \\
\hline & 2-4 times a week & 0 & 9.7 & \\
\hline & More than 5 times a week & 6.5 & 3.2 & \\
\hline
\end{tabular}

A significant difference is also identified between the pretest and post-test percentages of the answers to the item "Other children spoke ill of me, ridiculed me or nicknamed $m e^{\prime \prime}\left[X_{9)}^{2}=21.630, p<.05\right]$. When the answers of the children are examined, while a decrease is being observed in the post test percentages of the children who said "Never", there has been an increase in the post test percentages of the children who said "once a week" and "more than 5 times a week". On the other hand, there has been no change in the test percentages of the children who said "2-4 times a week".

A significant difference is also identified between the pretest and post-test percentages of the answers to the item "Other children did not let me join them" $\left[X^{2}{ }_{9)}=33.940\right.$, $p<.05]$. An increase is determined in the post test percentages of the children who said "Never" and "more than 5 times a week"; a decrease is determined in the post test percentages of the children who said "once a week". On the other hand, no change has been observed in the test percentages of the children who said "2-4 times a week".

A significant difference is determined between the pretest and post-test percentages of the answers to the item "Other children took the things that belonged to me". $\left[X_{(9)}^{2}=29.431, p<.05\right]$. When the answers are examined, an increase in the post test percentages of the children who said "Never" and "more than 5 times a week" and a decrease in the post test percentages of the children who said "once a week" and "2-4 times a week". 
There is not a significant difference between the pre-test and post-test percentages of the answers to the item "Other children threatened to hurt me and to take my objects" $\left[X^{2}(6)=2.588, p>\right.$.05]. While a decrease is seen in the post test percentages of the children, who said "once a week" and "more than 5 times a week", an increase is seen in the post test percentages of the children who said "2-4 times a week". No change is observed in the test percentages of the children who said "Never".

Table 3. The Chi-square Test Results about the Comparison of the Pre-Test and Post-Test for the Places Where the Children Suffer From Bullying

\begin{tabular}{lrr}
\hline Place Where I Suffer From Bullying & Pre-test (\%) & Post-test (\%) \\
\hline Classroom & 47.6 & 33.3 \\
Garden & 0 & 23.8 \\
Hallway & 9.5 & 19.0 \\
Toilet & 4.8 & 9.5 \\
Round trip road to school & 28.6 & .484 \\
Canteen & 0 & 9.5 \\
Nowhere & 9.5 & 4.8 \\
\hline
\end{tabular}

The pre-test shows that the children mostly (47.6\%) have suffered from bullying in classrooms, then respectively "the round trip road to school" (28.6\%), "hallway" (9.5\%) and "toilet" (4.8\%). Children left "the canteen" and "the garden" options empty. $9.5 \%$ of the children gave the answer "nowhere" to this question. When the post test results are examined, though there has been a decrease in the percentages of the children, who has given the answer "classroom"(33.3\%), even so it is determined that they have suffered from bullying in the class at most. "Garden"(23.8\%) and "hallway"(19.0\%) follow this answer. It is seen that the post-test percentages of "toilet" and "round trip road to school" is the same as 9.5\%. "Canteen" is at last with $4.8 \%$. According to the answers given by the children, it is seen that there has not been a significant difference between the pre-test and post-tests $\left[X^{2}(20)=\right.$ $19.580, p>.05]$.

Table 4. The Chi-square Test Results about the Comparison of the Pre-test and Post-tests for by Whom the Children Were Bullied

\begin{tabular}{|c|c|c|c|}
\hline The Bully & Pre-test (\%) & Post-test (\%) & $p$ \\
\hline A girl in the same class with me & 0 & 10.5 & \\
\hline A boy in the same class with me & 36.8 & 31.6 & \\
\hline A girl in an upper grade & 0 & 5.3 & \\
\hline A boy in an upper grade & 21.1 & 42.1 & .274 \\
\hline Girls in the same class with me & 5.3 & 0 & \\
\hline Boys in the same class with me & 31.6 & 10.5 & \\
\hline None & 5.3 & 0 & \\
\hline
\end{tabular}

In the pre-test for the determination of by whom the children were bullied, it is seen that the item " $A$ boy in the same class with me" has the highest percentage (36.8\%) and the item "Boys in the same class with me" (31.6\%) follows this answer. The percentage of the third item " $A$ boy in an upper grade" is $21.1 \%$. While it is determined that $5.3 \%$ of the children have been bullied by the girls from the same class with themselves, it is identified that $5.3 \%$ of the children have answered the question as "none". When the post test is examined, it is seen that the item "A boy in an upper grade" has the highest percentage $(42.1 \%)$ and the followed item is "A boy in the same class with me" $(31.6 \%)$. While it is determined that the percentages of the items "A girl in the same class with me" and "Boys in the same class with me" have remained the same $(10.5 \%)$, it is identified that the percentage of the ones that have given the item "A girl in an upper grade"has been $5.3 \%$. It is seen that there has not been a significant difference between the pre-test and post-tests percentage to the items of the children $\left[X^{2}(16)=18.906\right.$, p>.05].

Table 5. The Chi-square Test Results About The Comparison of The Pre-Test and Post-Tests for The People to Whom The Children Told About The Bullying

\begin{tabular}{|c|c|c|c|}
\hline To whom did you tell the bullying? & Pre-test (\%) & Post-test (\%) & $p$ \\
\hline Nobody & 45.5 & 59.1 & \multirow{4}{*}{.691} \\
\hline To a friend & 9.1 & 22.7 & \\
\hline To an adult at school & 18.2 & 4.5 & \\
\hline To mother-father & 27.3 & 13.6 & \\
\hline
\end{tabular}

When the people to whom the children had told about the bullying are examined, while it is seen that the ones, who have given the answer "Nobody", were $45.5 \%$ and the ones who had told to their mothers and fathers have followed this answer with $27.3 \%$ in the percentages of the pre-test. $18.2 \%$ percent of the children told about the 
bullying that they had suffered to an adult at school and $9.1 \%$ told to a friend. The ones who have given the answer "Nobody" have been the first (59.1\%) and this had been followed by the ones who had given the answer "to a friend" with $22.7 \%$ at post-test. While the percentage of the ones, who had told about it to their mothers and fathers were $13.6 \%$, it is observed that there is a decrease in the percentage of the ones who had told an adult at school (4.5\%). It is identified that there is not a significant difference between the pre-test and post-test according to the answers of the children $\left[X^{2}(9)=6.480, p>.05\right]$.

Table 6. The Chi-square Test Results about the Comparison of the Pre-Test and Post Tests for the Bully Behaviours of the Children and Their Frequency

\begin{tabular}{|c|c|c|c|c|}
\hline In this period & & Pre-test (\%) & Post-test (\%) & $p$ \\
\hline \multirow{4}{*}{ I hit or kicked the other children } & Never & 51.5 & 42.4 & \multirow{4}{*}{.944} \\
\hline & Once a week & 33.3 & 24.2 & \\
\hline & 2-4 times a week & 12.1 & 15.2 & \\
\hline & More than 5 times a week & 3.0 & 18.2 & \\
\hline \multirow{4}{*}{$\begin{array}{l}\text { I spoke ill of the other children, } \\
\text { ridiculed them or nicknamed them }\end{array}$} & Never & 64.5 & 58.1 & \multirow{4}{*}{.803} \\
\hline & Once a week & 19.4 & 22.6 & \\
\hline & 2-4 times a week & 12.9 & 12.9 & \\
\hline & More than 5 times a week & 3.2 & 6.5 & \\
\hline \multirow{4}{*}{$\begin{array}{l}\text { We did not let the other children join } \\
\text { us }\end{array}$} & Never & 81.8 & 72.7 & \multirow{4}{*}{.382} \\
\hline & Once a week & 6.1 & 21.2 & \\
\hline & 2-4 times a week & 9.1 & 6.1 & \\
\hline & More than 5 times a week & 3.0 & 0 & \\
\hline \multirow{4}{*}{$\begin{array}{l}\text { I took the objects that belong to other } \\
\text { children. }\end{array}$} & Never & 90.6 & 90.6 & \multirow{4}{*}{.133} \\
\hline & Once a week & 6.3 & 3.1 & \\
\hline & 2-4 times a week & 3.1 & 6.3 & \\
\hline & More than 5 times a week & 0 & 0 & \\
\hline \multirow{4}{*}{$\begin{array}{l}\text { I threatened the other children to } \\
\text { hurt them or to take their objects. }\end{array}$} & Never & 93.5 & 80.6 & \multirow{4}{*}{.916} \\
\hline & Once a week & 6.5 & 6.5 & \\
\hline & 2-4 times a week & 0 & 9.7 & \\
\hline & More than 5 times a week & 0 & 3.2 & \\
\hline
\end{tabular}

There is no significant difference between the pre-test and post-test percentages of the answers given to the item "I hit or kicked the other children" $\left[X_{(9)}^{2}=3.451\right.$, $p>$.05]. A decrease is observed in the percentages of the children who said "Never" and "once a week"; an increase in observed in the percentages of the children who said "2-4 times a week" and "more than 5 times a week".

A significant difference is not determined between the pre-test and post-test percentages of the answers given to the item "I spoke ill of the other children, ridiculed them or nicknamed them" as well $\left[X^{2}{ }_{(\rho)}=5.345, p>.05\right]$. When the answers given by the children are examined, while a decrease is being observed in the post test percentages of the children, who said "Never", there was an increase in the post test percentages of the children who said "once a week" and "more than 5 times a week". On the other hand, there was no change in the post test percentages of the children who said "2-4 times a week".

A significant difference is not identified between the pretest and post-test percentages of the answers given to the item "We did not let the other children join us", as well $\left[X^{2}{ }_{(6)}=6.384, p>.05\right]$. A decrease in the post test percentages of the children, who said "Never", "2-4 times week" and "more than 5 times a week" and an increase in the post test percentages of the children who said "once a week" is determined.

No significant difference is identified in the pre-test and post-test percentages of the answers given to the item "I took the objects that belong to other children" $\left[X^{2}{ }_{(4)}=\right.$ $7.049, p>.05]$. No change is observed in the percentages between the answers "Never" and "more than 5 times a week" in the pre-test and post-test. On the contrary, it is seen that there is a decrease in the post test percentages of the children who said "once a week" and an increase in the post test percentages of the children who said "2-4 times a week".

There is a significant difference between the pre-test and post-test percentages of the answers given to the item "I threatened the other children to hurt them or to take their objects" $\left[X_{(3)}^{2}=.513, p<.05\right]$. A decrease in the post test percentages of the children who said "Never" and an increase in the post test percentages of the children who said "2-4 times a week" and "more than 5 times a week" are mentioned. There is no change in the post test percentage of the children who said "once a week".

Table 7. The Chi-Square Test Results About The Comparison of The Pre-Test and Post-Tests For The People Who Were Bullied by Children

\begin{tabular}{lrrr}
\hline The one whom I bully & Pre-test (\%) & Post-test (\%) & $p$ \\
\hline In the same class with me & 61.9 & 61.9 & .488 \\
In a lower grade & 9.5 & 4.8 & .4 .8
\end{tabular}


When Table 7 is examined, it is determined that the children had mostly bullying the children, who were in the same class with them and these children have the same percentages in both test applications (61.9\%). An increase (33.3\%) in the post test percentages of the children who said "In an upper grade" and a decrease (4.8\%) in the post test percentages of the children who said "In a lower grade" is observed. No significant difference is identified between the pre-test and post-test applications about this article $\left[X^{2}{ }_{(6)}=5.450, p>.05\right]$.

Table 8. The Chi-square Test Results about the Comparison of the Pre-Test and Post-Tests for the Places Where the Children Bully

\begin{tabular}{|c|c|c|c|}
\hline Place where I bully & Pre-test (\%) & Post-test (\%) & $p$ \\
\hline Classroom & 50.0 & 22.7 & \\
\hline Garden & 13.6 & 22.7 & \\
\hline Hallway & 4.5 & 31.8 & \\
\hline Toilet & 9.1 & 13.6 & .605 \\
\hline Round trip road to school & 13.6 & 9.1 & \\
\hline Nowhere & 4.5 & 0 & \\
\hline All of them & 4.5 & 0 & \\
\hline
\end{tabular}

The pre-test results of the children indicate that the place where they bully mostly had been the class $(50.0 \%)$, then respectively the garden (13.6\%), round trip road to school (13.6\%) and toilet (9.1\%). 4,5\% of the children said "none, hallway and all of them" to this question. When the answers of the post test is examined, a decrease (22.7\%) is seen in the percentages of the children, who said that the place where they bully was "the class" and a serious increase is seen (31.8\%) in the percentages of the children who said that the place where they bully had been "the hallway". "The classroom" and "the garden" is following the "the hallway" with $22.7 \%$. It is determined that the ones who said "the toilet" is $13.6 \%$ and the ones who said "round trip road to school" is 9.1\%. "None" and "All of them" is at last with $4.8 \%$. They left "none" and "all of them" options empty. It is seen that there is no significant difference between the pre-test and post-tests according to the answers given by the children $\left[X^{2}(24)=21.562, p>.05\right]$.

\section{Discussion, Conclusions and Recommendations}

When it is looked at the frequencies of the bully behaviours that the children suffer from, while a significant difference is being determined in favour of the post-test in the items "Other children hit or kicked me", "Other children did not let me join them" and "Other children took the things that belong to me", a significant difference is being determined in favour of the pre-test in the item "Other children spoke ill of me, ridiculed me or nicknamed me". On the contrary, no significant difference was identified in the article "Other children threatened to hurt me or to take my objects". It can be said that there has been a decrease in the bully behaviours the children suffer from in general.

The children stated in both tests that they have mostly been bullied in the classrooms. A similar result about the bullying of the children mostly in the class was also found by Özkan and Gökçearslan (2010). Again Kartal and Bilgin (2008) stated in their studies that the children mostly have been bullied in the classroom. However, Çınkır and Karaman Kepenekçi (2003) determined that the bullying mostly had occurred in the school garden and secondly in the classroom. In the analyses of this study, a significant difference in the people, who bully the children, is out of question. When the percentages are examined, the children stated in the pre-test that they have mostly been bullied by a boy in the same class with them and in the post test that they have mostly been bullied by a boy in an upper grade. Bullying of the children by the boys in both tests might be about the majority of the participants that constituted of mostly boys. In the study carried out by Özkan and Gökçearslan (2010), it was concluded that mostly boys were bullying. A similar conclusion was determined in the studies carried out by Çınkır and Karaman Kepenekçi (2003), Kartal and Bilgin (2008) and Kartal (2009).

It is determined that the people to whom the children have told about the bullying had not shown a significant difference and that they had preferred no one to tell this in both tests. This case may be interpreted as the children did not want to tell the bullying they suffer from to others in order not to be seen weak. In the study of Kartal and Bilgin (2008), the children stated that they had told about the bullying they suffer from to no one too.

There is no significant difference in the pre-test and posttests of the bully behaviours of the children and their frequencies. In a qualitative study performed for taking the opinions of the same sample group about "Bir Umut Ol Benim için" project, a child stated that "My behaviors have changed. I behave well to others. I used to involve in a fight before, now I wait for a while."This opinion of the child shows that the project caused positive changes in bully behaviours of some children. Uysal (2006) identified that "Education Program against Violence" conducted with seventh grades had not caused a significant difference in the bully behaviour points of the children too. However no significant difference is determined in the people who were bullying by children and in the places where the children bully. The children stated that they have mostly bullying the people in the same class with them.

When all these results are evaluated, it is concluded that "Bir Umut Ol Benim İçin" project has not had a positive 
effect on the bully behaviours of the children. Although it was hoped that the project contributed to disadvantaged children in this regard, the negative results obtained are evaluated as an expected situation since the process had not been a proof program from bullying. Eslea and Smith (1998) after the application of a school wide biennial program against bullying, stated that the number of children, who had said that they have been bullied, had decreased and in the next year while this situation remained the same in a school, it had begun to increase in another school. In the end of another application carried out by Stevens and his friends (2000), it was specified that though the frequency of suffering from bullying have remained the same, there had been significant decreases in the levels of bullying. Pepler and his friends (1994), in the end of their study, found that while the frequency of suffering from bullying was decreasing, on contrary the frequency of bullying others have increased. Epstein, Plog and Porter (2000), in the end of a four-year program, did not encounter a reduction in exclusion rates despite the reduction in physical and oral bullying (Beran \& Tutty, 2002). However Uysal (2006) stated that the "Education Program against Violence" which he has conducted with seventh grades had increased the conflict resolution abilities of the children and had significantly decreased their tendency to violence. Hence it is thought that bully proofing programs must be supported with conflict resolution programs. Thus the child will be learning to find a solution to bullying that he suffered from with his conflict resolution abilities. In addition it was observed that "Awareness towards Violence" program conducted by Düzgün, Alibeyoğlu and Orhan (2006) had increased the awareness of the children for violence and violent behaviours and that the children have developed behaviours. These two studies show that the programs devoted to protect from bullying or violence have caused positive results.

From this point of view, it may be suggested that the studies that would be carried out with disadvantaged children to be performed by including the program of protection from bullying and the program of conflict resolution abilities. The study is a quantitative study and it is thought that the deep analysis of the results obtained would make significant contributions to the field. Accordingly, these kinds of studies may be supported with qualitative studies. Also teacher observations may be included. Because, the majority of the participants consisted of boys caused to obtain restricted data about the roles of the girls in bullying process. Performing these kinds of analyses with sample groups, in which the girls are at quorum, is another suggestion of the study. The long term success of the bullying protection programs is possible with the cooperation of teachers, school staff, family members and children.

\section{Recommendations}

When it is looked at the frequencies of the bully behaviors that the children suffer from, while a significant difference is being determined in favor of the post-test in the items "Other children hit or kicked me", "Other children did not let me to join themselves" and "Other children took the things that belong to me", a significant difference is being determined in favor of the pre- test in the item "Other children spoke ill of me, ridiculed me or nicknamed me". On the contrary, no significant difference was identified in the article "Other children threatened me to hurt me or to take my objects". It can be said that there have been a decrease in the bully behaviors the children suffer from in general.

The children stated in both tests that they have mostly been bullying in the class. A similar result about the bullying of the children mostly in the class was also found by Özkan and Gökçearslan (2010). Again Kartal and Bilgin (2008) stated in their studies that the children mostly have been bullying in the class. However Çınkır and Karaman Kepenekçi (2003) determined that the bullying mostly had occurred in the school garden and secondly in the class. In the analyses of this study, a significant difference in the people who bully the children is out of question. When the percentages are examined, the children stated in the pre-test that they have mostly been bullying by a boy in the same class with them and in the post test that they have mostly been bullying by a boy in an upper class. Bullying of the children by the boys in both tests might be about the majority of the participants that constituted of mostly boys. In the study carried out by Özkan and Gökçearslan (2010), it was concluded that mostly boys had bullying. A similar conclusion was determined in the studies carried out by Çınkır and Karaman Kepenekçi (2003), Kartal and Bilgin (2008) and Kartal (2009).

It is determined that the people to whom the children have told the bullying had not shown a significant difference and that they had preferred no to tell this to anyone in both tests. This case may be interpreted as the children did not want to tell the bullying they suffer from to others in order to be seen weak. In the study of Kartal and Bilgin (2008), the children stated that they had told the bullying they suffer from to no one too.

There is no significant difference in the pre-test and posttests of the bully behaviors of the children and their frequencies. In a qualitative study performed for taking the opinions of the same sample group about "Bir Umut Ol Benim İçin" project, a child stated that "My behaviors have changed. I behave well against others......... I used to involve in a fight before, now I wait for a while." This opinion of the child shows that the project caused positive changes in bully behaviors of some children. Uysal (2006) identified that "Education Program against Violence" conducted with seventh classes had not caused a significant difference in the bully behavior points of the children too. However no significant difference is determined in the people who were bullying by children and in the places where the children bully. The children stated that they have mostly bullying the people in the same class with them.

When all these results are evaluated, it is concluded that "Bir Umut Ol Benim İçin" project has not had a positive effect on the bully behaviors of the children. Although it was hoped that the project to have contributed to disadvantaged children in this regard, the negative results obtained are evaluated as an expected situation since the process had not been a proof program from bullying. Eslea and Smith (1998) after the application of a 
schoolwide biennial program against bullying, stated that the number of children who had said that they have been bullying had decreased and in the next year while this situation have been remaining the same in a school, it had begun to increase in another school. In the end of another application carried out by Stevens and his friends (2000), it was specified that though the frequency of suffering from bullying have remained the same, there had been significant decreases in the levels of bullying. Pepler and his friends (1994), in the end of their study, found that while the frequency of suffering from bullying was decreasing, on contrary the frequency of bullying others have increased. Epstein, Plog and Porter (2000), in the end of a four-year program, did not encounter a reduction in exclusion rates despite the reduction in physical and oral bullying (Beran \& Tutty, 2002). However Uysal (2006) stated that the "Education Program against Violence" which he has conducted with seventh classes had increased the conflict resolution abilities of the children and had significantly decreased their tendency to violence. Hence it is thought that bully proofing programs must be supported with conflict resolution programs. Thus the child will be learn to find a solution to bullying that he suffered from with his conflict resolution abilities. Again it was observed that "Awareness against Violence" program conducted by Düzgün, Alibeyoğlu and Orhan (2006) had increased the awareness of the children for violence and violent behaviors and that the children have developed behaviors that away after the program. These two studies show that the programs devoted to proof from bullying or violence have caused positive results.

From this point forth, it may be suggested that the studies that would be carried out with disadvantaged children to be performed by including the program of proof from bullying and the program of conflict resolution abilities. The said study is a quantitative study and it is thought that the deep analysis of the results obtained would have significant contributions to the field. Accordingly, these kinds of studies may be supported with qualitative studies. And teacher observations may be included. Since the majority of the participants are constituted of boys caused to obtained restricted data about the roles of the girls in bullying process. Performing these kinds of analyses with sample groups in which the girls are at quorum is another suggestion of the study. The long term success of the bullying proofing programs is possible with the cooperation of teachers, school staff, family members and children.

\section{References}

Bademci, V. (2006). Güvenirliği doğru anlamak ve bazı klişeleri yıkmak: bilinenlerin aksine, cronbach'ın alfa katsayısı, negatif ve "-1"den küçük olabilir. Inönü Üniversitesi Eğitim Fakültesi Dergisi, 712), 3-26.

Bauman, S., \& Del Rio, A. (2005). Knowledge and beliefs about bullying in schools: comparing pre-service teachers in the United States and The United Kingdom. School Psychology International, 26(4), 428442.

Beran, N.T. \& Tutty, L. (2002). An Evaluation of the dare to care: bully proofing your school program, final report.
Retrived from http://www. ucalgary.ca/resolv e/files/dare_to_care.pdf.

Byrne, B. (1994). Bullies and victims in a school setting with reference to some Dublin schools. The Irish Journal of Psychology, 15(4), 574-586.

Connor, D.F. (1998). Over categorical aggression in referred children and adolescents. Journal of the American Academy of Child and Adolescent Psychiatry, 671), 66-73.

Çınkır, Ş. \& Karaman Kepenekci, Y. (2003). Öğrenciler arası zorbalık. Kuram ve Uygulamada Eğitim Yönetimi. 34, 236-253.

Dash, M. (2007). Education of exceptional children. Atlantic Publishers and Distributors (p) LTD, New Delhi.

Düzgün, E., Alibeyoğlu, M.C. \& Orhan, F. (2006). "Şiddete karşı farkındalık" öğretim programının etkililiği ve öğrenci görüşleri. Bildiri Özeti. I. Şiddet ve Okul: Okul ve Çevresinde Çocuğa Yönelik Şiddet ve Alınabilecek Tedbirler Sempozyumu, 28 - 31 Mart 2006, İstanbul.

Ersanlı, E. (2007). Okullarda şiddet ve çocuk suçluluğu, Adem Solak (Ed). Ankara: Anı Yayıncılık.

Eslea, M. \& Rees, J. (2001). What age are children most likely to be bullied at school? Agressive Behavior, 276), 419-429.

Garrity, C., Jens, K., Porter, W., Sager, N. \& Short-Camilli, C. et al. (2000). Bully-proofing your elementary school, (2d ed.) . Longmont, Colorado: Sopris West.

Griffin, R.S. \& Gross, A.M. (2004). Childhood bullying: Current findings and future directions for research. Aggression and Violent Behavior, 9, 379-400.

Kartal, H \& Bilgin A. (2007). İlköğretim öğrencilerine yönelik bir zorbalık karşıtı program uygulaması: okulu zorbalıktan arındırma programı. Eğitimde Kuram ve Uygulama. Uournal of Theory and Practice in Education). 3(2), 207-227.

Kartal, H \& Bilgin A. (2008). Öğrenci, veli ve öğretmen gözüyle ilköğretim okullarında yaşanan zorbalık. ilköğretim Online. 72), 485-495. Retrived from http://ilkogretim-online.org.tr.

Kartal, H. (2009). öğretmen adaylarının uygulama okullarındaki zorbalıkla ilgili değerlendirmeleri. Gazi Eğitim Fakültesi Dergisi. 29(1). 141-172.

Kırcaali-iftar, G. (2007). Özel gereksinimi olan diğer öğrenciler. S. Eripek (Ed.), illköğretimde Kaynaştırma. Eskişehir: Anadolu Üniversitesi Yayınları, 125-137.

Moore, K.A. (2006). Defining the term at risk. Researchs to Results Child Trends. http://www.childtrends.org/Files /DefiningAtRisk\%5B1\%5D.pdf.

Olweus, D. (1987). Schoolyard bullying - Grounds for intervention. School Safety, Fall:4-11.

Olweus, D. (1993). Bullying at school- What we know and what we can do. Oxford: Blackwell Publishers. 
Olweus, D. (1999a). Sweden. In Smith, P.K., Morita, Y., Junger-Tas, J., Olweus, D., Catalano, R., \& Slee, P. (Eds). The Nature of School Bullying: A Cross-National Perspective. London \& New York: Routledge, 7-27.

Özkan, Y. \& Gökçearslan E. (2010). Düşük sosyo-ekonomik düzeydeki ilköğretim okullarında akran zorbalığı. ilköğretim Online. 9(2), 576-586. Retrived from http://ilkogretim-online.org.tr.

Pepler, D.J., Craig, W.M., Ziegler, S. \& Charach, A. (1994). An evaluation of an anti-bullying intervention in Toronto schools. Canadian Journal of Community Mental Health, 132(2), 95-110.

Sarpdağ, M. (2005). Çocuk suçluluğu ve polis. Ankara:Ahsen Matbaacılık.

Scarpaci, R. (2006). Bullying: Effective strategies for its prevention. Kappa Delta Pi Record, 42, 170-174.

Schatz, J.N; Smith, L.E; Borkowski, J.G; Whitmen, T.L. \& Keogh, D.A. (2008), Maltreatment risk, self-regulation and maladjustment in at-risk children. Child Abuse And Neglect. 32, 972-982.

Smith, T. E., Polloway, E.A., Patton, J.R., \& Dowdy, C.A. (2004). Teaching students with special needs in inclusive settings (4th ed.). Boston, MA: Pearson.

Stevens, V., de Bourdeaudhuij, I, \& Van Oost, P. (2000). Bullying in Flemish schools: an evaluation of antibullying interventions in primary and secondary schools. British Journal of Educational Psychology, 70, 195-210.

Uysal, A. (2006). Şiddet karşıtı programlı eğitimin öğrencilerin çatışma çözüm, şiddete eğilim ve şiddet davranışlarına yansıması. Bildiri Özeti. I. Şiddet ve Okul: Okul ve Çevresinde Çocuğa Yönelik Şiddet ve Alınabilecek Tedbirler Sempozyumu, 28 - 31 Mart 2006, İstanbul. 
This page is intentionally left blank www.iejee.com 